\title{
Comparison of Transforming Growth Factor-Beta 1 Concentration in Preeclampsia and Normal Pregnancy Women
}

\author{
Yusrawati $^{1, *}$, Dyka Aidina ${ }^{2}$, Eti Yerizel $^{3}$ \\ ${ }^{1}$ Division of Maternal-Fetal Medicine, Department of Obstetrics and Gynecology, Faculty of Medicine, Andalas University, Jl. Perintis Kemerdekaan \\ No.94, Padang, Indonesia \\ ${ }^{2}$ Faculty of Medicine, Andalas University, Jl. Perintis Kemerdekaan No.94, Padang, Indonesia \\ ${ }^{3}$ Department of Biochemistry, Faculty of Medicine, Andalas University, Jl. Perintis Kemerdekaan No.94, Padang, Indonesia \\ ${ }^{*}$ Corresponding author. E-mail: yusrawati_65@yahoo.co.id
}

Received date: Jan 13, 2017; Revised date: Mar 2, 2017; Accepted date: Mar 24, 2017

\section{Abstract}

B ACKGROUND: According to the theory of endothelial dysfunction, the pathogenesis of preeclampsia is associated with the imbalance of angiogenic and anti-angiogenic factors. Transforming growth factor-beta 1 (TGF- $\beta 1$ ) has also proposed as a proangiogenic factor that influences preeclampsia. This study was conducted to compare a mean difference of TGF- $\beta 1$ between preeclampsia and normal pregnancy.

METHODS: This study was an observational crosssectional study with 25 subjects of pregnant women with preeclampsia and 25 subjects of normotensive pregnant women. The study was conducted in Dr. Reksodiwiryo Hospital, Bhayangkara Hospital, and Dr. Rasidin Hospital in Padang, Indonesia from October 2015 to January 2016. For the determination of TGF- $\beta 1$ concentration, peripheral venous blood samples were taken. The blood samples were analyzed by enzyme-linked immunosorbent assay (ELISA) in Biomedical Laboratory, Faculty of Medicine, Andalas University. The mean difference was statically analyzed by independent samples T-test.

RESULTS: The mean difference of TGF- $\beta 1$ was lower in preeclampsia group than normal pregnancy group $(2.02 \pm 0.99 \mathrm{ng} / \mathrm{mL} v s .3 .24 \pm 2.67 \mathrm{ng} / \mathrm{mL} ; p<0.05)$.

CONCLUSION: The TGF- $\beta 1$ concentration was lower in pregnant women with preeclampsia. Thus, it may have a role as a marker in preeclampsia.

KEYWORDS: preeclampsia, normal pregnancy, transforming growth factor-beta1, TGF- $\beta 1$

Indones Biomed J. 2017; 9(1): 49-52

\section{Introduction}

Preeclampsia is a major complication in pregnancy and a leading cause of death and also maternal and perinatal morbidity. Globally, $10-15 \%$ of maternal deaths are directly related to preeclampsia and eclampsia. According to WHO, preeclampsia/eclampsia is the second leading cause of morbidity and mortality in pregnant women.(1) The incidence of preeclampsia is different in each country, it ranges between $2-8 \%$ of all pregnancy.(2)
Preeclampsia/eclampsia is still called a disease of theory. Various studies have not been able to explain precisely the exact cause of the disease. According to the theory of endothelial dysfunction, the pathogenesis of preeclampsia is associated with angiogenic and anti-angiogenic factors. The imbalance in both of these factors will affect trophoblast invasion and spiral artery remodeling.(3) Angiogenic and anti-angiogenic protein have been widely studied in pregnant women with preeclampsia. The concentration of angiogenic and anti-angiogenic factors of mother plasma/serum has been proposed as a parameter 
that can help to identify women with preeclampsia potential.(4)

Angiogenic protein that has widely known is vascular endothelial growth factor(VEGF). Soluble fms-like tyrosine kinase-1 (s-Flt-1) is a protein antagonist which is able to decrease the vasodilatation by reducing the level of free circulating VEGF that can lead to hypertension.(5) Besides VEGF, transforming growth factor-beta 1 (TGF- $\beta 1$ ) have also proposed as a pro-angiogenic factor that influences preeclampsia.(6) TGF- $\beta$ family plays a role in the endothelial cell growth and angiogenesis, affect the nature of immune responses and can affect various functions of trophoblasts.(7)

The previous studies had reported inconsistent results about the association of TGF- $\beta 1$ with preeclampsia. Hennessy, et al., stated that there were no differences in the levels of TGF- $\beta 1$ in high-risk pregnant women that ended with preeclampsia and normal pregnant women.(8) Meanwhile, another study showed that TGF- $\beta 1$ was significantly lower in the preeclamptic group than in normal pregnancy.(9) In another side, Enquobahrie, et al., reported that Zimbabwe women with preeclampsia tend to have a higher TGF- $\beta 1$ than normal pregnant women.(10) The possibility of TGF- $\beta 1$ as a marker for preeclampsia and the inconsistent results which were found in the previous studies have intrigued the writers to study the differences in mean serum levels of TGF- $\beta 1$ in the preeclamptic patients and normal pregnancies.

\section{Methods}

This was an observational study with a cross-sectional design. This study conducted from October 2015 to January 2016 and was approved by The Committee of Medical Research Ethics of Dr. M. Djamil Hospital. The population was the pregnant women after 20-week gestations in maternal ward and clinic of Dr. Reksodiwiryo Hospital, Bhayangkara Hospital, and Dr. Rasyidin Hospital in Padang, Indonesia. A total of 50 subjects were included in this study and were took by consecutive sampling. The pregnant women after 20-week gestations, who diagnosed as preeclampsia (25 subjects) and normal pregnancy (25 subjects), were willing to follow this research, and had a singleton pregnancy, were included in this study. Meanwhile, the exclusion criteria were subject with systemic inflammation (leukocytes $>16,000$ $\mu \mathrm{L})$, multiple pregnancies, and history of diabetes mellitus, dyslipidemia, kidney, or heart disease. The gestational age was matched in the two groups.
After providing informed and agree to participate in this study by written consent, $3 \mathrm{~mL}$ of peripheral venous blood samples were collected from antecubital vein to analyze the TGF- $\beta 1$ concentration. The blood then stored in the cool box and sent to the Biomedical Laboratory, Faculty of Medicine, Andalas University immediately to be centrifuged for 10-15 minute. The separated serum then was brought to the laboratory to analyze the TGF- $\beta 1$ concentration by using enzyme-linked immunosorbent assay (ELISA) method with Elabscience TGF- $\beta 1$ ELISA Kit (Elabscience, Hubei, China).

Normality test was analyzed by Shapiro-Wilk test. The Independent samples t-test then used to determine the significant difference. Statistical analysis was conducted using the SPSS ver 22.0.

\section{Results}

The subject characteristics are presented in Table 1. The age, parity, body mass index, hemoglobin, and leukocytes of the subjects were higher in women with preeclampsia than in women with normal pregnancy. As shown in Table 2 , the mean concentration of serum TGF- $\beta 1$ was lower in preeclampsia than normal pregnancy $(2.02 \pm 0.99 \mathrm{ng} / \mathrm{mL} v s$. $3.24 \pm 2.67 \mathrm{ng} / \mathrm{mL} ; p<0.05)$.

\section{Discussion}

Our study found the mean concentration of serum TGF- $\beta 1$ was lower in preeclampsia than normal pregnancy $(p<0.05)$. Our study result was in accordance with the systematic review study in eight case-control studies which concluded the TGF- $\beta 1$ concentration was significantly lower in preeclampsia group in the second trimester but significantly higher in the third semester.(9) Clausen, et al., found that there was a significantly lower concentration level of TGF- $\beta 1$ in women with eventual preeclampsia, compared to the controls healthy pregnant women $(3.2 \mathrm{ng} / \mathrm{mL} v s .5 .3$ $\mathrm{ng} / \mathrm{mL} ; p=0.01)$.(11) Our study was also in accordance with a study by Lim, et al., which found that TGF- $\beta 1$ were lower in preeclampsia group $(p<0.001)$.(12)

The previous study found that there was an imbalance between the placenta pro-angiogenic and anti-angiogenic factors in preeclampsia which may harm vascular endothelial and make the clinical symptoms of the mother. The existence of TGF- $\beta 1$ as a pro-angiogenic factor in pregnancy, are needed to assist in the maturation of blood vessels in the placenta.(5) 
Table 1. The subject characteristics of the study.

\begin{tabular}{lccc}
\hline & Preeclampsia & Normal Pregnancy & \multirow{2}{*}{$\boldsymbol{p}$ value * } \\
\cline { 2 - 3 } & Mean \pm SD & Mean \pm SD & \\
\hline Mother Age (year) & $32.2 \pm 3.9$ & $30.6 \pm 4.5$ & 0.201 \\
Gestational Age (week) & $37.9 \pm 1.0$ & $37.6 \pm 0.94$ & 0.319 \\
Parity & $2.3 \pm 1.5$ & $2.04 \pm 1.36$ & 0.497 \\
Body Mass Index $\left(\mathrm{kg} / \mathrm{m}^{2}\right)^{\#}$ & $23.9 \pm 2.0$ & $22.7 \pm 2.19$ & 0.057 \\
Hemoglobin $(\mathrm{g} / \mathrm{dL})$ & $11.1 \pm 0.9$ & $10.5 \pm 1.20$ & 0.064 \\
Leukocytes $(/ \mu \mathrm{L})$ & $12222 \pm 2619$ & $8228 \pm 1449$ & 0.000 \\
\hline
\end{tabular}

* $p$ values are obtained by independent t-test.

"Body Mass Index before pregnancy

Table 2. Comparison of TGF- $\beta 1$ in preeclampsia and normal pregnancy.

\begin{tabular}{|c|c|c|c|c|}
\hline & \multirow{2}{*}{$\begin{array}{c}\text { Preeclampsia } \\
\text { Mean } \pm \text { SD }\end{array}$} & \multirow{2}{*}{$\begin{array}{c}\text { Normal Pregnancy } \\
\text { Mean } \pm \text { SD }\end{array}$} & \multirow{2}{*}{$\begin{array}{c}\text { Mean Difference } \\
(95 \% \mathrm{CI})\end{array}$} & \multirow{2}{*}{$p$ value* } \\
\hline & & & & \\
\hline TGF- $\beta 1(\mathrm{ng} / \mathrm{mL})^{\#}$ & $2.02 \pm 0.99$ & $3.24 \pm 2.67$ & $1.22(2.38-2.54)$ & 0.041 \\
\hline
\end{tabular}

* $p$ values are obtained by independent t-test.

${ }^{*}$ Body Mass Index before pregnancy

In preeclampsia, there is disruption of trophoblast invasion in the spiral arteries that result in the destruction spiral arteries which cause the decreasing blood flow in the intervillous space. The decreasing uteroplacental blood flow can cause placental hypoxia that may lead to the release of toxic substances such as cytokines (tumor necrosis factor (TNF)- $\alpha$, interleukin (IL)-6) as a reaction to the inflammatory response and increased anti-angiogenic factors such as soluble endoglin (sEng) and s-Flt-1. Increased sEng anti-angiogenic factors will alter the process of interaction between TGF- $\beta 1$ and its receptors (Eng) and can make TGF- $\beta 1$ decreased. This will inhibit angiogenesis and apoptosis that causing endothelial dysfunction.(13) Another theory was that the inhibition of normal TGF signaling by sEng played a role in placental dysfunction secondary to vascular damage that can lead to placental hypoxia and increased production of s-Flt-1 and sEng.(14)

Although sEng has been suggested to be a biomarker of the severity of preeclampsia, the association of TGF- $\beta 1$ with preeclampsia was still conflicting nowadays. A study in Peruvian women found the TGF- $\beta 1$ concentration were $42 \%$ higher in cases than in control $(18.4 \pm 1.0 \mathrm{ng} / \mathrm{mL} v s$. $13.0 \pm 0.8 \mathrm{ng} / \mathrm{mL}, p<0.001)$.(15) It is relevant with a study by Naicker, et al., which reported that TGF- $\beta 1$ significantly increased in plasma of all the preeclamptic patients compare to the normotensive pregnant group $(4.9 \pm 0.2 \mathrm{ng} /$ $\mathrm{mL}$ vs. $1.9 \pm 0.54 \mathrm{ng} / \mathrm{mL}, p<0.001)$.(16) Most of the studies which showed the increase of TGF- $\beta 1$ concentration were conducted in pregnant women in their third trimester of pregnancy. Meanwhile, the previous study that relevant with our study mostly carried out in the subject in their second trimester of pregnancy. Whether the decrease level of TGF- $\beta 1$ in the second trimester is responsible for the systemic inflammation in preeclampsia patients or the increased level of TGF- $\beta 1$ is one of preeclampsia trigger or consequence of preeclampsia are still unclear. In our study, the mean gestational age of the subjects was 37 with the majority of the subjects were in their third trimester. However, we did not differ the subjects into the two trimesters so we cannot detect any difference of TGF- $\beta 1$ in the two trimesters.

The inconsistent of the results may also occur because of many factors such as the difference in gestational age of the subjects, the assay techniques, the study design and the blood processing procedures.(9) Review of the literature showed that different methods and protocols were giving various ranges of the TGF- $\beta 1$ concentration.(16) Moreover, maternal systemic inflammatory status and the distributions 
of the severity of preeclampsia could also play a role in the dissimilarity of the finding.(15)

We just assessed only a single sample obtained during this gestational period, so how long the TGF- $\beta 1$ concentration had altered prior to the onset of preeclampsia cannot be determined either. It is recommended to give some comments on the findings which was in accordance with the two trimester pregnant women although the subjects of study were in the third trimester

\section{Conclusion}

The TGF- $\beta 1$ concentration was lower in pregnant women with preeclampsia compared to normal pregnant women. The TGF- $\beta 1$ may play a role as a marker in preeclampsia.

\section{References}

1. Bender RM, Ryan GL. Pre-eclampsia and eclampsia: global challenges in low resource settings complete with proposed interventions in rural Haiti. Proc Obstet Gynecol. 2013; 3: 1-6.

2. Duley L. The global impact of pre-eclampsia and eclampsia. Semin Perinatol. 2009; 33: 130-7.

3. Keman K, Prasetyorini, Langgar MJ. Perbandingan eksprei p53, Bcl2, dan indeks apoptosis trofoblas pada preeklampsia/eklampsia dan kehamilan normal. Maj Obstet Ginekol Indones. 2009; 33: 151-9.

4. Levine RJ, Lam C, Qian C, Yu KF, Maynard SE, Sachs BP, et al. Soluable endoglin and other circulating antiangiogenic factors in preeclampsia. N Engl J Med. 2006; 355: 992-1005.

5. Maynard SE, Karumanchi A. Angiogenic factors and preeclampsia. Semin Neprol. 2011; 31: 33-46.
6. Bilezikjian LM, Blount AL, Donaldson CJ, Vale WW. Ptuitary actions of ligands of the TGF-beta family:activins and inhibins. Reproduction. 2006; 132: 207-15.

7. Chen Q, Chen L, Liu B, Vialli C, Stone P, Ching LM, Chamley L, The role of autocrin TGF $\beta 1$ in endothelial cell activation induced by phagocytosis of necrotic trophoblasts:a possible role in the pathogenesis of pre-eclampsia. J Pathol. 2010; 221: 87-95.

8. Hennesy A, Orange S, Willis N, Painter DM, Child A, Horvath JS. Transforming growth factor- $\beta 1$ does not relate to hypertension in pre-eclampsia. Clin Exp Pharmacol Physiol. 2002; 29: 968-71.

9. Li X, Shen L, Tan H. Polymorphisms and plasma level of transforming groowth factor-beta 1 and risk for preeclampsia: a systematic review. PlosS ONE. 2014; 9: e97230. doi: 10.1371/journal.pone.0097230.

10. Enquobahrie DA, Williams MA, Qiu C, Woelk GB, Mahomed K. Maternal plasma transforming growth factor- $\beta 1$ concentrations in preeclamptic and normotensive pregnant Zimbabwean women. J Maternal Featl Neonatal Med. 2005; 17: 343-8.

11. Clausen T, Djurovic S, Resesland JE, Berg K, Drevon CA, Henriksen T. Altered plasma concentration of leptin, transforming growth afctor- $\beta 1$ and plasminogen activator inhibitor type 2 at 18 weeks of gestation in women destined to develop pre-eclampsia. Circulating markers of disturbed placentation? Placenta. 2002; 23: 380-5.

12. Lim JH, Kim SY, Park SY, Lee MH, Yang JH, Kim MY, et al. Soluble endoglin and transforming growth factor- $\beta 1$ in women who subsequently developed preeclampsia. Prenat Diagn. 2009; 29: 4716.

13. Santibanez J, Quintanilla M, Bernabeu. TGF- $\beta$ receptor system and its role in physiological and pathological conditions. Clin Sci. 2011; 121: 233-51.

14. Robinson CJ, Johnson DD. Soluble endoglin as a second trimester marker for preeclampsia. Am J Obstet Gynecol. 2007; 197: 174. e1-5.

15. Muy-Rivera M, Sanchez SE, Vadachkoria S, Qiu C, Bazul V, Williams MA. Transforming growth factor- $\beta 1$ in plasma is associated with preeclampsia risk in Peruvian women with systemic inflammation. Am J Hypertens. 2004; 17: 334-8.

16. Naicker T, Khedun SM, Moodley J. Transforming growth factor $\beta 1$ levels in platelet depleted plasma in African women with preeclampsia. J Obstet Gynecol. 2002; 22: 279-82. 